\title{
Elected Neighbourhood Officers in a Turkish City (Izmir): Gendered Local Participation in Governance
}

\author{
Fatma Şenol
}

[Paper first received, June 2010; in final form, May 2012]

\begin{abstract}
This paper explores how gender differences and the local scale influence individuals' conditions (i.e. motivations/issues, resources and styles) for inclusion in formal politics as electoral candidates and then as officers. The experiences of women and men muhtars_elected resident-officers of neighbourhoods-in Izmir (Turkey) in 2008 provided the data. It appeared that political participation via neighbourhood offices is shaped by (in)formal mechanisms of power relations that have been historically male-dominated with patriarchal rule(r)s at the neighbourhood level and with clientelist and statist ones at multiple scales. Men were supported greatly by their gendered neighbourhood-based networks. Women with male backing, including of incumbent muhtars, had better chances. All of the muhtars aimed at guiding residents through the governmental system, experiencing that the centralised state undermined muhtars' representative roles. By following certain tactics a few, mostly women, muhtars were persistent enough to participate in the governmental system that operated through patron-client relationships.
\end{abstract}

\section{Introduction}

Borrowed from a tradition in the Ottoman Empire before 1923, Turkey has a mechanism of citizen participation at the neighbourhood scale: a public office at and for each urban neighbourhood. Elected among and by the residents of each neighbourhood, these resident officers (or muhtars) assist central and local governments in registering information about residents and administering residents' needs for urban and social services, and even informally deal with family problems. However, the facts that neighbourhood offices have no authority within formal mechanisms of governance and that a low percentage of muhtars are women undermine these offices'

Fatma Şenol is in the Department of Urban Planning, Izmir Institute of Technology, IYTE, Kampus Mimarlik Fak., E-Blok, Gülbahçe Köyü/URLA, Izmir, 35430, Turkey. Email: fatmasenol@iyte.edu.tr. 
potential for developing participatory local governance in Turkey.

A case study about these neighbourhood offices, this paper discusses gendered and local aspects of participation in governance. It assumes that, due to conditions based on gender, race, ethnicity, class and other characteristics, many groups are marginalised and lack active and passive inclusion in formal politics, which causes injustice in society. To improve such groups' inclusion in formal politics, the conditions for their political participation must be identified. Based on my interviews with 23 female and 20 male muhtars in a metropolitan Turkish city (Izmir) in 2008, this study asks whether and how the conditions (i.e. motivations/ issues, resources and styles) for inclusion in politics evolved differently among these residents during the electoral recruitment, election and at the office at neighbourhood level. It presumes participation and representation in formal politics to be complementary forms of 'citizenship', or citizens' daily practices to become part of collective decision-making about the redistribution of societal resources (Lister, 1997). Within the conditions shaped by their individual characteristics and various institutional factors, the study respondents discussed their participation in formal decision-making as electoral candidates and then as muhtars.

Examining the arguments that identify women's human agency around gendered responsibilities and the local scales as pivotal for improving citizens' participation in governance, this study relies on various works in development studies, political science and political geography, especially within feminist approaches. These works re-identify political participation as a process for not necessarily representing, but 'making citizens' (Turnhout et al., 2010). They consider the 'spaces of participation' (Cornwall, 2004) as reconstructed with dynamic power relations based on citizens' actual socioeconomic conditions within informal and formal mechanisms, rules and engagements (Cleaver, 2004) across multiscales of governance (Beall, 2007; Garcia, 2006). Within these spaces, participants might express their human agency to a degree enabled by their social contexts that evolve along with their actual and expected gender roles and responsibilities, age, class and other characteristics and their groups' histories and experiences of power relations at multiple scales (Cleaver, 2004; Wedel, 2001). Here, 'power' appears as differential control over or access to material and symbolic resources (Cornwall, 2004) and 'gender' becomes "a primary way of signifying relationships of power" rather than only "a constitutive element of social relationships based on perceived differences between the sexes" (Scott, 1999, p. 42).

This paper comparatively investigates women's and men's gendered experiences when participating in formal politics at and via the neighbourhood scale. It differs from the majority of studies that either focus only on women and identify the neighbourhood as the scale only for women's political recruitment or examine gendered participation in formal politics only via national elections and offices. It considers that, at local scales, the structures of power (basically patriarchy and capitalism) operate in relation to those various scales. These multiscalar power relations are mediated by the nation-state (Garcia, 2006; Marston, 2000; Swyngedouw, 2005) and by various past and current formal and informal relations and mechanisms of power (Beall, 2007) including family, community, social networks, workplaces, organisations and legal regulations (Cleaver, 2004; Staeheli and Clarke, 1995; Wedel, 2001). At their daily practices within these mechanisms, individuals might develop certain 'tactics'-or "the innumerable practices through which users appropriate the space organized by 
techniques of sociocultural production" (de Certeau, 1984, p. xiv) — and to some degree, negotiate their status within dominant power relations.

My central findings suggest that the women's and men's main drive for candidacy was to find a paid job or charity work near their homes/local communities. When developing motivations and resources for political participation, men appeared to be a natural part of mechanisms of power relations, with informal networks guided by local patriarchal rule(r)s and clientelist ones in the governmental system. Facing the undermined status of local offices within the strong-state tradition of Turkey, most of the muhtars were resigned to their administrative, rather than representative, duties. A few respondents, often women, developed certain tactics to get these mechanisms' 'permission' for their public visibility via the office.

\section{Gender and the Neighbourhood Scale at Political Participation}

With the challenges to the state territoriality and territorially based electoral representation (Urbinati and Warren, 2008), the role of the state as the locus of collective decisions is argued to be replaced by the governance in which the state is expected to collaborate with various actors from the public, private and voluntary sectors. With its new technologies of ruling (Swyndegouw, 2005), governance requires a shift from representative to participatory democracy that expects citizens to be involved in more interactive state-and-citizen relationships or decision-making for 'efficient' provision and management of public services (Beall, 2005; Garcia, 2006).

Underlining the uneven conditions for political participation among citizens, however, there is increasing evidence that defies these expectations. Overall, via elections, social movements, civic organisations and other means, citizens intend to take part in decision-making about the redistribution of societal resources and thus exercise a prior right of citizenship (Lister, 1997). Yet because of race, ethnicity, gender, class and other characteristics, certain groups lack the opportunities for active and passive inclusion (Urbanati and Warren, 2008)-or, descriptive and substantive representation - in formal politics and are marginalised. To have a just society with equal opportunities, it is crucial to improve the political participation of marginalised groups such as women. Such improvements might be descriptive by increasing the number of women holding offices, or substantive by bringing to formal politics the distinct knowledge, perspectives and values on issues that affect women differently than men (Lovenduski, 2001; Phillips, 1995). The first step is to re-identify the uneven conditions for political participation among individuals and groups, which is what this study aims at.

Why do the conditions for political participation vary among citizens? Studies in political science explain this in relation to individual and/or institutional characteristics. Focusing usually on the national scale in Anglo-Saxon contexts, most of the studies about gendered participation in formal politics identify the conditions for women's entry into politics, while only a few examine elected officers' conditions for representing citizens. The former argue that women lack the individual characteristics for taking public office-such as social class, education level, group networks, available time and occupational, political or public service experiences (Verba et al., 1995). Because patriarchal relations expect women to prioritise their traditional responsibilities, women are socialised into non-competitive backgrounds that might not accord with 
recruitment for public offices. Men more frequently engage in activities that foster skills for these offices (Evertzen, 2001; Verba et al., 1995). Institutional factors (for example, social structures with norms and expectations about gender roles, political cultures and electoral systems) also determine women's limited access to skills, training and mentors for formal politics (Norris and Inglehart, 2000). Whereas women's participation in the paid labour force may appear as a determinant of women's presence in offices (Studlar and McAllister, 1991), egalitarian attitudes towards women in office are affected negatively by strict religious norms (Evertzen, 2001) but positively in post-industrial societies (Norris and Inglehart, 2000). Even women with credentials according to the 'masculine candidate model' have barriers to candidacy (Studlar and McAllister, 1991), due to the 'gatekeepers' (for example, financial supporters, political party leaders and members), social prejudices (Norris and Inglehart, 2000) and the persisting male incumbency (SchwindtBayer, 2005).

At the elected offices, the environmental factors of political institutions might be supportive of female officers or be genderbiased, with the male-dominated networks, the culture of masculinity and the work conditions incompatible with women's family responsibilities (Appelbaum et al., 2003; Eagly, 2007; Lovenduski, 2005). Meanwhile, female politicians tend to focus on educational, health and welfare issues, while men work on business and private economic concerns (Thomas, 1994, cited in Wängnerud, 2009). Similarly, women's and men's attitudes and leadership styles might have feminine and masculine characteristics that carry distinct advantages to those leaders and institutions. Usually displayed by women, feminine characteristics might be communication skills as an empathetic listener, developed interpersonal skills and advanced intermediary skills for conflict resolution. Masculine characteristics include businessoriented skills, including instruction giving, and autocratic attitudes (Appelbaum et al., 2003; Eagly, 2007; Studlar and McAllister, 1991).

To improve marginalised groups' inclusion in politics, both the local scales and these groups' (especially women's) 'transformative' power are shown as significant. The local offices are expected to control weaker hierarchies of power relations than at 'grand' scales and thus provide marginalised groups with more opportunities for entry into formal politics (Phillips, 1995). Also, the closer proximity between locally elected representatives and constituents might improve the design and implementation of effective policies (Fisher and Kling, 1993), especially for more 'gender-sensitive' local services (Evertzen, 2001). Moreover, the immediacy of the local community in people's lives is argued to support more motivations and resources for organised citizen involvement in collective decisionmaking about neighbourhoods (Fisher and Kling, 1993). In particular, women are expected to be active through local networks, movements or organisations regarding their gendered house- and neighbourhood-keeping roles and responsibilities (Evertzen, 2001; Naples, 1998; Staeheli and Clarke, 1995; Wedel, 2001). Similarly, women's entry into formal politics is emphasised for adequate representation of certain interests that arise in women's experiences differently than in men's (Phillips, 1995).

However, political participation of individuals and at local scales is not necessarily transformative. Individuals' exercises of human agency are shaped by the 'spaces of participation' that are infused and reconstructed with dynamic power relations (Cornwall, 2004) along with individuals' socioeconomic contexts across multiple 
realms (Beall, 2005; Marston, 2000). With their multiple identities (for example, as wives, daughters and mothers), individuals might act according to the relationships of morality, mutuality and interdependence in their communities (Cleaver, 2004; Wedel, 2001). The ways that participation is organised might evolve not to represent citizens and pre-existing local perspectives, but to construct new forms of citizen involvement and perspectives (Turnhout et al., 2010) or even to reinforce existing power relations (Cornwall, 2004; Swyngedouw, 2005). Moreover, the power relations shaping participation at local scales are not limited to there but are interplayed with those at multiple scales. By its agencies and regulations for redistributing wealth and welfare entitlements, the nation-state in particular 'mediates' these multiscalar relations (Beall, 2007; Garcia, 2006; Staeheli and Clarke, 1995; Swyngedouw, 2005).

Within this framework, various studies across non-Anglo-Saxon contexts underline multiple (in)formal mechanisms, norms, rules and engagements of power relations at local scales that usually hinder women's entry into formal politics. Such mechanisms and engagements reproduce social prejudices against women for acting in nontraditional gender roles and tend to ostracise them from politics (Beall, 2005; Wedel, 2001). Moreover, whereas local governments are vulnerable to these mechanisms and engagements, women are historically excluded from them-for example, the 'chieftaincy' based on male hereditary principles in African countries (Beall, 2005, 2007). Here, female candidates with male backing might have more advantages over other women (Arat, 1989; GüneşAyata, 1991). Also, local governments might deploy unreasonable bureaucratic control extended by central government (Beall, 2005). Similarly, undermining local offices, the centralised state system in
Turkey neglects the electoral procedures for neighbourhood offices, which encourages the persistence of male incumbency over new (and usually women's) candidacies (Senol, 2009).

Meanwhile, there is a need for more comparative investigations about female and male elected officers' conditions for representing citizens, and what percentages of female officers are necessary to represent a 'women's perspective' effectively in political matters (Güneş-Ayata and Tütüncü, 2008; Lovenduski, 2001). Some of the characteristics in articulating policy priorities and leadership styles and attitudes might relate not to gender but rather to class, ethnicity, institutional positions, party ideologies, newness and seniority of the politicians (see Wängnerud, 2009; Urbinati and Warren, 2008). Also, as a non-exclusive domain of either gender, effective leaderships with particular feminine or masculine styles can be learned (Eagly, 2007).

Considering these arguments, the following section describes the neighbourhood offices within the Turkish governmental system and examines female and male respondents' conditions for political participation at electoral recruitment, during the election and while serving in the office in Izmir.

\section{Study Findings}

Each urban neighbourhood in Turkey has an office with a muhtar and a council, both elected by and among that neighbourhood's residents every five years without any consecutive term limit. Neighbourhood offices are administrative, non-governing units. There are three types of local government, all under the control of the Ministry of the Interior. Each provincial government has a governor appointed by the central government and a council elected by provincial 
votes. Within provinces, the provincial centre and the settlements with a population above 5000 have a municipal government with a mayor and a council, both elected by local votes. Outside the municipal boundaries, there are village administrations with a council and a muhtar, both elected by villagers.

As the central government's smallest unit in the province but within municipal boundaries, the neighbourhood offices assist the central administration by registering, confirming, declaring and notifying various matters about and to residents and all governing units. In practice, muhtars often work with municipal governments. According to the Municipalities Law (dated 2005); the municipalities might aid neighbourhood offices in kind and muhtars can join but not vote in the municipal commissions. With more limited rights than the state employees, muhtars have no staff but receive a salary (less than the minimum wage) bolstered by paperwork fees from residents. In big neighbourhoods with high rates of residential turnover, the sum of these fees gets so high that a lot of muhtar candidates might run expensive campaigns that might include fraud and fights.

Such complications within neighbourhood offices are related to the argument that the Ottoman state during the 19th century created the units of local governments as part of a new administration system (Köker, 1995) and the neighbourhood offices to 'fill the (administrative) void' at the local level (Arıkboğa, 1999). This system was to restore state power and to improve the tax collection system, rather than to install decentralised governance. Maintaining this statist-centralist and the strong-state tradition, the Turkish Republic (1923) has kept this 'guardianship' role that put the local governmental units in a "subordinate position with purely administrative and nonpolitical roles" (Köker, 1995, p. 60).
Neither the Empire nor the Turkish Republic recognised neighbourhood offices as governing units partially due to the 'modernisation' of the state according to the European traditions of administering the public work at the city, rather than the neighbourhood, scale (Arıkboğa, 1999).

Similarly, as the main task of the nationbuilding projects by the Republic, Turkish citizenship was constructed with more "duties" than "rights" and as "civilized" and "militantly active in the process of serving for the making of modern Turkey" with a national secular identity (Keyman and İçduygu, 2003, p. 231) that has defied the representation of different demands in the decision-making process. Since the 1950s and especially the 1980s, Turkey's centralist and strong-state tradition and monolithic republican citizenship have been challenged by rapid urbanisation, religious, ethnic and sectarian movements (Köker, 1995), changes among global-national-local relationships and the process of Turkey's integration into the European Union as a full-member candidate (Keyman and İçduygu, 2003). A part of such challenges, the women's movement has gained partial victories for gender equality-for example, with the adoption of the New Civil Code and the amendment of the Penal Code in the 2000s (Güneş-Ayata and Tütüncü, 2008). Since the 1990s, the women's movement has diversified with Islamist, Kemalist, leftist and Kurdist characteristics (Sancar-Üşür, 2003).

Of approximately all 18500 neighbourhood offices today, only 2.31 per cent are held by women. From 2004 to 2009, the ratio of female officers increased in municipal (2.5 per cent to 4.5 per cent) and provincial (1.7 per cent to 3.26 per cent) councils (Ministry of Interior, 2011), with the rate varying across the regions (Arikboga et al., 2010) and increasing the most in metropolitan cities (Alkan, 2009). In contrast to world-wide trends, these ratios are lower 
than in the Turkish parliament (9.1 per cent in 2007 and 14.18 per cent in 2011 , the highest since the first election with women's candidacies in 1935). These lower ratios can be explained by the settlement size: the municipalities with 100000 people or less have stronger patriarchal rules and thus lower ratios of female officers (Çitci, 1989). These ratios are worse in rural municipalities (i.e. settlements with 20000 or less people) than urban municipalities (respectively, 1.7 per cent and 11.6 per cent in 2009) (Arıkboğa et al., 2010). Also, the women's movements in Turkey related women's issues only to national policies and 'the local scale' mostly to families' economic needs, rather than to political representation (Sancar-Üşür, 2003; Alkan, 2009). Since the 1990s, however, the Association for the Support and Training of Female Candidates has been campaigning for women's entry into the formal politics even at neighbourhood level.

With more than 3.5 million people and 26 municipalities, Izmir has a higher ratio of women in municipal councils (14.47 per cent in 2004 and 14.07 per cent in 2009), better socioeconomic indicators and higher shares of the labour force in the manufacturing and the service sectors and of rural immigration than the national averages. Out of 438 neighbourhood offices in Izmir in 2008, women held 36 . Of these, 30 were in the three central municipalities (Konak, Karsiyaka and Bornova), which have 55 per cent of all neighbourhood offices, 48 per cent of the total city population, Izmir's highest urban densities and percentages of high school and college graduates similar to Izmir's (26 per cent) but above the national average (21 per cent) (TUIK, 2008). With the women's share in municipal councils around Izmir's average, these municipalities became my study site in 2008 .

I was able to interview 23 of 30 female muhtars and 20 male muhtars with the female respondents' suggestions about "a male muhtar of a nearby neighbourhood". Tape-recorded and transcribed, each interview lasted from one to two hours at neighbourhood offices. I used pseudonyms for the respondents. Interview questions were about the kind of motivations, issues, resources and styles these muhtars had during electoral recruitment, the election and the office in respect to their gender, class, education level, local networks and other characteristics; to the expectations and role definitions they and to their community had about muhtar's roles and responsibilities; and to their experiences with the laws, regulations and governmental offices. When analysing the data, I focused on how the respondents' individual characteristics had interplayed with each other within various social and institutional contexts and how this had shaped the respondents' conditions for political participation, detailed in what follows.

\section{Electoral Recruitment and Candidacy}

Independent from political parties, any literate Turkish citizen over 25 years old can run for office in her/his neighbourhood, if $\mathrm{s} /$ he has been officially living there for six months or more. It is commonly known that muhtars are typically over-middle-aged male retirees or local merchants. In Turkey, elected officers have been mostly men with a higher socioeconomic level than that of most muhtars and the average electorates. Parliamentarians have had university education and claims to an intellectual and official occupational status, and are generally well-known in their provincial communities (Arat, 1989). Female parliamentarians have had educational and occupational status, by the 1980s, almost equal to (Arat, 1989) and better than that of male parliamentarians in the 2000s (Güneş-Ayata and Tütüncü, 2008). Since the 1980s, with local politics becoming "a distributive sphere of 
urban rents" (Alkan, 2009), most municipal and provincial offices have been held by local businessmen and merchants.

This study found that, with the individual characteristics as significant resources for entering into formal politics (for example, occupational status, education level and political experiences) (Verba et al., 1995), female and male respondents had different advantages. Prior to their candidacies, most of the men had retired from service or manufacturing jobs and were also running a neighbourhood store. Of the women, nearly half were retired from or had service jobs, most were better educated and slightly younger, with an average age in their early 40 s when taking the office.

Relatively lacking in most 'formal' resources, women in Turkey (Wedel, 2001) and in other contexts (Evertzen, 2001; Naples, 1998) generally develop local networks as a resource for participating in politics. This study found that such networks were significant for both men's and women's entry into formal politics and evolved within various local mechanisms of power relations (Beall, 2005; Cleaver, 2004). Being homeowner-occupants for more than 20 years, all of the respondents were connected to certain neighbourhoodbased networks. Women were more frequently involved in political parties, charity work and voluntary organisations. Men were members in a greater variety of local organisations, mostly those with exclusively male members.

This section details how such characteristics of the respondents interacted with each other within various social contexts and were mobilised as a resource for women's and men's candidacies. As a storytelling tool, I initially highlighted the respondents' primary reason for candidacy as the "candidate profiles". These reasons surely overlap at each respondent's reality and do not determine the respondents' will and office work for getting involved in formal decision-making. Three similar profiles appeared among women and men (Political-career-seekers, Job-seekers and Charity-workers) and another one only of men (Brotherly-supported-peers). Around these profiles, I detailed the respondents" motivations and resources for candidacy, some of which were shaped by certain gatekeepers (i.e. those with a power in and/or over the respondents' social contexts)namely the spouses, 'prominent neighbours', local peer networks, and incumbent muhtars.

Candidates and Gatekeepers. In contrast to a common expectation that the local offices might be the first step to a career in formal politics, I found that few female (2 out of 23) and male (3 out of 20) respondents ran for the neighbourhood office with this motivation. Now in their mid 40s and third term of office, the female Political-career-seekers took the office during their 30s. They had prior experience only in political parties, whereas the male Political-career-seekers had none. Now in their first term and early 50s, these men became candidates in ways similar to those of the Brotherly-supported-peers, explained later.

Recently unemployed or retired, and looking for an additional income, none of the male Job-seekers (6 out of 20) had prior involvement in parties or voluntary organisations. The female Job-seekers (13 out of 23) perceived this office as a local job "suitable to middle-aged-women" with family responsibilities, similar to female candidates in a smaller city (Senol, 2009). Their background was more versatile than those of the male Job-seekers and other female respondents. Half of them had experience with charity work, and most of the women with political party membership were among 
them. Only half had job experience, onand-off, in the service sector. A secretary before, Emine (45, with a middle income and a college degree) decided for candidacy when she was 31 and searching for a job after raising her children

Friends at our local women's organisation told me to become a muhtar. I and my husband investigated muhtars' responsibilities and decided for my candidacy.

Emine's joint action and decision with her spouse was a rare case among all the respondents. In Turkey, a joint decision for woman's candidacy with the household, which is sometimes done on behalf of the men, seemed to be common among female parliamentarians (Güneş-Ayata, 1991), but less so for women in municipal offices (Arat, 1989). In this study, asking their spouses' 'permission' for their candidacies was common among women, but among only a few men. Most of the women said that they asked their husband's permission usually "out of courtesy", rather than as the final word of male patriarchal rulers in the women's extended family-which was the case in a smaller city (Senol, 2009) where stronger patriarchal restrictions had probably restricted women's public visibility (Çitci, 1989). Some of the women became candidates even though their husbands were initially concerned about "her safety at the office with various visitors". These husbands were only convinced after the election when the close proximity between the office and home provided convenient opportunities for them and family members to visit the office and sometimes assist their wives/mothers. These findings tentatively suggest that, for a woman's candidacy for the neighbourhood office, the husband's permission might be enough, due to this office's close proximity to the local community's control, whereas for the offices at upper scales with higher stakes and more public visibility, the extended family's collective action and decision might be more necessary.

Joint decisions for women's candidacies were also encouraged by 'prominent neighbours', particularly for recent widows with a limited income. Fatma (60, with a low income, secondary school qualification and no job experience) negotiated such a communal decision for herself 20 years ago

Neighbours and friends wanted me running for candidacy. I was still mourning for my husband. [Hesitated] I asked my elder neighbours' advice. They said: "We raised you; we trust you; we don't want another candidate". The ex-incumbent's kids also supported me. But I was afraid that people would disapprove me in the office. Then one of our elder sisters in the neighbourhood assured me: "Nobody could [dare to] say anything". I became a candidate.

Usually male and sometimes female elders with long-term residency in the neighbourhood, as prominent neighbours acted like patriarchal rulers in the family, but for their community based on the relationships of morality, mutuality and interdependence (Cleaver, 2004; Wedel, 2001), especially in smaller and relatively stable neighbourhoods.

Yet in all neighbourhoods, the incumbent muhtar as a prominent neighbour played a critical role, especially for women's candidacies. Generally with office-based resources and networks, re-running muhtars have advantages over other candidates (Senol, 2009; Arıkboğa, 1999). In this study, a few of the male but nearly all of the female respondents finalised their decisions for candidacy only after knowing that their incumbent muhtars were not re-running - departing due to ageing or dying. Afterwards, these incumbents' support in various forms was 
important for new candidates. Prior to candidacy, a significant group of men and women (including more than half of the female Job-seekers) were their incumbent muhtars' paid assistants and/or family members. As the paid assistant, some of the female Job-seekers got their departing incumbent's 'blessing' and support, often with office-based resources. If their incumbent was dying then a prominent neighbour often encouraged his wife or daughter to consider candidacy. This communal decision was made in order to keep that family's financial status and even a 'neighbourhood tradition' with certain male hereditary principles (Beall, 2005). Ayse (45, with a middle income, high school qualification and no job experience) explained this

As muhtar of this neighbourhood (since 14 years), I am the third generation in my family. Before his death, my father was muhtar for 40 years. He was considering me as his successor. My brother already had a job.

Without prior relation to incumbents, a few female Job-seekers and nearly half of the female Charity-workers got their departing incumbent's support by becoming his assistant for free just briefly before the election. Prior to candidacy, nearly all of the female Charity-workers (8 out of 23) were usually involved in parent-teacher associations. They perceived the office as a 'stronger' ground for social work. Half of them were retired and the rest had no paid job experience. All retired (4 out of 20) before their candidacies, only half of the male Charityworkers had experience in party politics and various local associations.

Just before their candidacies, all of the Charity-workers were either retired, had ended their involvement in voluntary associations or had a health/family crisis. They were looking for "something to get busy, rather than wasting time" (for men) at coffee- houses or (for women) at home. For half of the female Charity-workers, either neighbours or their husbands worried about her "unrest staying at home" and thus encouraged her for candidacy. This was the case for Yildiz's husband, who "didn't want (her) having a paid job but charity work". For wives and mothers in Turkey, charity work seems to be suitable if these are in their neighbourhood or children's school, but usually does not improve women's public visibility (Sancar-Üşür, 2003). Completing her work at a parent-teacher association, Yıldiz was encouraged for candidacy by her husband working locally. However, he soon regretted it, according to Yildiz (41, with middle income, a high school qualification and two teenage children)

He said: “(I know) you won't stay at home; you'll search for other organisations. Why not work in the neighbourhood?" He supported me working close to home and his control. Yet he wasn't expecting that as a muhtar I would extend my networks and trips outside the neighbourhood. Now he uncomfortably says: "You're this neighbourhood's administrative chief; but I'm your chief".

His support declined probably due to his expectations about his wife's responsibilities being embedded at home and in the neighbourhood, rather than her ignorance of these responsibilities. Similar to most of the elected female officers in Turkey (Arat, 1989; GüneşAyata, 1991), Yildiz and other female muhtars structured their lives within the responsibilities of traditional housewives.

Of the men, the Brotherly-supportedpeers ( 7 out of 20) also imagined their candidacies and office work as a 'service to their neighbourhood'. They differed from other men in the versatility of their prior experiences, which were mostly neighbourhood-based. Nearly all were running a local 
store. Half of them had previously been their muhtar's paid assistant. Most of them were involved in local branches of political parties and various local voluntary organisations. As with the other male respondents, they were encouraged for candidacy by their local male peer groups. However, these groups acted as the decision-maker for candidacies, as Kenan (30, single, with a middle income, a college degree and a local family business) summarised

Our seniors, big brothers, elected me to run as a candidate because we were against certain candidates. They would not give any service to our neighbourhood.

Identifying the neighbourhood as their collective unit with interdependence among themselves, these peer groups evaluated candidates' party and ideological ties, economic needs and "intentions for supporting the poor or solving local problems" and selected a candidate usually "among those of (their) own". These men had become peers since their adolescence in that neighbourhood by socialising locally in coffeehouses (only for men) or stores and/or at a variety of local organisations mainly with male members - for example, mosque charity organisations, local football clubs or hometown associations.

\section{At the Office: "Foot Servants of the System"}

During this study, half of all the respondents had been muhtars for one or two terms while the rest had up to eight terms (i.e. 40 years). This section identifies the respondents' conditions in the office in relation to their perceptions of the 'good' muhtar and of how residents and governmental units approached neighbourhood offices and muhtars, and to the issues, resources and styles they deployed as muhtars.
Generally disappointed in the office, most of the respondents identified the primary responsibility of muhtars as guiding, rather than representing, residents within the governmental system. They argued that the process from the election to the office suggested "as if muhtars have some authority, but they don't”. Calling themselves an "unauthorised authority" and "the foot servant of bureaucratic burdens", they had accepted their roles in order to fill an administrative void at the local level (Arikboga, 1999). However, they also complained that the governmental units were not legally obliged to involve muhtars in developing neighbourhood projects, even though local residents held muhtars primarily responsible for these projects. Moreover, these units asked for muhtars' participation, usually in such ways that challenged muhtars' limited resources and authority, or required muhtars to 'fix problems' usually after the projects were completed, according to Emine

With my neighbourhood maps and documents, I visited many government offices. Some officers there told me why I bother myself with such details. Surely I do, because residents would put the blame only on me for [that project's failures].... If I am the head of this neighbourhood, [public officers] should first come to me; show their projects; ask my opinion. Then I would get the residents' opinions about those projects. I have been asking for this but without success for 14 years.

As in Emine's case, muhtars must struggle daily to 'earn the respect' of government officials, in order to participate in decisionmaking, and also of residents as their elected representatives. Because of the neighbourhood offices' deprived status within Turkey's political and administrative system, some residents tended to undermine the muhtars' status. Residents of the neighbourhoods with mostly rural migrants 
expected muhtars to hold the legal power of muhtars of villages and complete bureaucratic works immediately (Arıkboğa, 1999). Also, some residents seemed to perceive muhtars as the state's 'powerful' local representatives and thus blame them, sometimes aggressively, for any failure in the state apparatus.

When (re-)arranging their issues, resources and styles at the office, most of the respondents were resigned to these conditions of neighbourhood offices and only less than half tended to challenge these, as detailed later. Of this small group, it was mostly women who were more persistent in their efforts, regardless of the impact made by these efforts.

Residents as the primary responsibility. The kinds of neighbourhood projects managed by the respondents varied mostly according to their neighbourhood's socioeconomic level and location in Izmir, rather than their gender. Both the central and peripheral neighbourhoods in this study had poor and better-off populations. Poor neighbourhoods had rural immigrants, including those from the south-east region of Turkey with Kurdish populations. Central poor neighbourhoods had an old physical structure but also recent urban renewal projects. Both new and old peripheral neighbourhoods had inadequate physical structures. Managing daily works for neighbourhood maintenance (such as the renewal of the sewage system and roads) were primary duties for all muhtars, but more often for those in the peripheral neighbourhoods. Projects for neighbourhood beautification (such as neighbourhood parks and street signs) were most commonly organised by female muhtars in the central neighbourhoods. Finding scholarships, food, used clothes and furniture for people in need was a common duty mostly among female muhtars.
However, rather than with the projects, nearly all of the respondents identified a 'good' muhtar in respect to her/his communication skills and social manners with residents-for example, welcoming, patient, informing and trustworthy in "never giving any false promises". These are not necessarily gender-specific characteristics, although most of the women argued that women with such skills developed by their traditional caring responsibilities were more effective in the office (Eagly, 2007). Muhtars seemed to underline these caring manners mostly as a reaction to their and the residents' lack of power in formal decisionmaking about neighbourhoods. Here, a common statement was that the muhtar must "first [be] tolerant [with residents], then [bring] services to the neighbourhood". A male muhtar of a poor peripheral neighbourhood, Avni (56, retired from a professional job, a high school graduate, a member of various local associations, first term in office) explained his reasoning for this statement

People here have been underdogs and deprived. Also, regardless of the muhtar's effort, the municipality is working or not working for the neighbourhood. Yet the muhtar must be kind with citizens.

A small group of female and male muhtars extended this "kindness" to include a "social responsibility" for solving residents' personal problems (for example, couple disputes, alcohol and drug addictions, unemployment and poverty) by calling the relevant public and private agencies, mediating among family members or just listening to residents (Arıkboğa, 1999). Ahmet (55, with a secondary school degree, a retired manager of the labour unions, second term in office) called this an undeniable responsibility due not to the laws, but to the social norms that required him 
to "return the mutual respect [out of which] residents ask for [the muhtar's] assistance".

In contrast to the majority of women, only some of the male muhtars carried this communal responsibility "only if residents ask for it". To explain this difference, some female muhtars argued that they were more "approachable" to any resident to talk about personal and family matters due to their better communicative skills (Appelbaum et al., 2003; Eagly, 2007) and gendered caring responsibilities. However, they also expressed the feeling that hearing and dealing with others' "too private" problems were often too exhausting for their own personal lives.

'Pushing' the governmental system. Only a few respondents underlined the muhtar's resources and style at working within the governmental system as significant for being a 'good' muhtar. Guided by other incumbents, all of the respondents learned to work within the state apparatus. To get public works, new muhtars usually sent petitions, although those with two or more office terms also tended to use their face-to-face contacts at governmental offices.

Besides willingness, developing such personal contacts required an assistant to the muhtar. Otherwise, when visiting governmental offices, the muhtar would have to close her/his office, thus reducing their daily fees from residents' paperwork. A very few male but nearly half of the female muhtars had at least one paid assistant from residents-usually a family member. Why was there this difference? Neighbourhood population size determined muhtars' income from the fees and thus the financial capacity to hire an assistant did not differ much between women and men. One explanation is that the women's family members joined her at the office because they worried about her being alone there and/or perceived her job in the neighbourhood as family work, whereas as the traditional breadwinners the men were expected to work by themselves. Or, women felt the need to work with governmental offices more persistently-the only feminine characteristic that women used advantageously at the office, according to most of the female respondents.

This study found that such persistency seemed to emerge in spite of the undermined status of neighbourhood offices and the male-dominated formal and informal networks in the governmental system. For a few but mostly the female muhtars, various daily tactics appeared as necessary in order to "push the system"-i.e. to get their demands for the neighbourhood. It was especially muhtars of the neighbourhoods with infrastructure problems who found that their "kind manners with residents" were inefficient within the state apparatus. They needed new manners, according to Pelin (female, 53, with prior experience in service jobs, first term of office)

I used to believe that I could get some public work that our ex-incumbent could not; he had temper. I thought that with politeness, I could make the municipality complete some work in my neighbourhood. It didn't happen. If there is a break in the chain [of processing my petition], works get delayed and I repeatedly must call each department.

Pelin now knew that to overcome any "break in the chain" of command for public works, muhtars must break the hierarchical order of the bureaucracy by being "less kind"-i.e. routinely calling or visiting the departments of bureaucracy and politics at different tiers. A few muhtars suggested "going to the top [i.e. the mayor] to get the work done". Hard to get an appointment with, the mayor was often accessible at public ceremonies. If the mayor or his 
support was unavailable, only a few female muhtars took their neighbourhood issues and complaints about "slow-responding municipalities" to the media news. This tactic of getting public attention sometimes brought them private donors' support and sometimes public offices' mixed and even "resenting" responses. These women were relatively familiar with the bureaucratic apparatus due to their better education level and/or family members in various public offices. Naciye (58, first term of office, a high school graduate, with two children-one a police officer and the other a journalist) explained why she used a non-governmental tool to push the system

In municipalities, works are done by crony relations [between citizens and officers]. If you don't follow up your petition persistently, your work won't get done.

Although transforming its form in respect to the changes in the state and civil society, such "crony" or patron-client relationships have been a major part of the administrative and political system at all levels in Turkey (Güneş-Ayata, 1994). To overcome the barriers to their access to public works, a few female and male muhtars were trying to be part of such patron-client relationships. They did this through their face-to-face contacts in governmental offices and in the neighbourhoods, where they often played 'host' to the various municipal and state employees-for instance, while offering tea-thus "making these employees to do their work with more care than usual", according to Naciye.

Interestingly, most of the respondents were less active with other organisational networks. They were involved in the Association of Muhtars as a way to get news about the city, neighbourhoods and laws and regulations. Some of them seemed to decline donations from the organisations "against the Kemalist ideology and the secular state". A few rejected any organisational donations in order "to avoid any expectation [that could harm] muhtars' independent status" from political parties or ideologies, as identified earlier (Arıkboğa, 1999).

Still when getting involved in (in)formal networks for public works, female muhtars had to be more tactful. This is because the majority of employees and officers were men and these networks were embedded with a history of patriarchal rule(r)s and maledominated gatekeepers (Beall, 2005; GüneşAyata, 1991; Lovenduski, 2005). To participate in certain formal networks, female muhtars-not only female candidates (GüneşAyata, 1991)—needed male backing, preferably by their husband. Şengül ( 55 , third term in office, with a high school qualification and and prior party membership) detailed this

I always wished that my husband join me at formal dinners; but he didn't. I was uncomfortable there alone. Male muhtars don't have such problems. Because the majority of muhtars are men, I feel excluded there. As muhtar, I always asked for my husband's emotional support.

Also, the muhtar's office and the (men-only) coffee-houses were the routine stops for all governmental officers and employees in the neighbourhood. Male muhtars used these places for networking with these employees, local peers and other neighbours. Yet some of the female muhtars underlined that they felt the urgency always to be alert about what was happening in the neighbourhood. Thus, a few women were encouraging residents to monitor the neighbourhood by taking pictures of and writing petitions about local problems, checking the current local public works and even offering tea to municipal workers there. 


\section{Conclusion}

Citizenship is a set of discourses and daily practices among and within social groups at local levels. This study found that, in both women's and men's experiences, the stages of participation (electoral recruitment, the election and the office) via neighbourhood offices were generally shaped by (in)formal mechanisms of power relations-for example, family, community, neighbourhood and public offices. These mechanisms have historically been dominated by patriarchal relations (Beall, 2005; Wedel, 2001), as well as, in Turkey, by clientelist (Güneş-Ayata, 1994) and centralist-statist relations (Köker, 1995; Keyman and İçduygu, 2003).

Within these mechanisms, men operated naturally and collectively, while women tried individually to get the support of patriarchal and clientelist networks. To be 'successful' at the level of recruitment and candidacy, all of the respondents were expected to act within the traditionally gendered communal responsibilities and, in office, to serve the administration of the central state. Through certain daily tactics (de Certeau, 1984), some of the respondents (usually women) were negotiating with the multilayered power relations of the structures of power (namely capitalism, patriarchy, clientelism and élitist-centralist statism) that were unfolding throughout such mechanisms. These tactics were to change not the respondents' legal citizenship status, but their rights for participating in the (in)formal decision-making process.

For candidacy, the close geographical and social proximity between the office and home motivated most of the women as expected (Evertzen, 2001; Fisher and Kling, 1993), but also the men. Women were poorer in the prior experiences (for example, education level, paid job and political experiences) that usually shape their formal resources for politics (Wedel,
2001) and with local networks-different from the literature (Naples, 1998). Men's certain formal resources were interwoven with their neighbourhood networks via organisations, local stores and coffeehouses. Supporting "those of [their] own", their peer groups were against the candidacy of women, newcomers, residents with ethnic, ideological or other differences, or sometimes incumbent muhtars. Despite their weak resources, female respondents seemed to win the election by getting male backing (Güneş-Ayata, 1991)-i.e. the resources of patriarchal rulers in their local community or, of husbands, prominent neighbours and incumbent muhtars. The close proximity between the office and home had convinced these gatekeepers that the female officers and all visitors to the office could be communally monitored to act within traditional gender roles. Similarly, the candidacy of recent widows and the wives or daughters of dying incumbents was a communal decision. Meanwhile, a significant group of women's prominent tactics were to acquire their departing incumbent's support.

At the office, the historically and legally marginalised status of neighbourhood offices (Arıkboğa, 1999) and of citizens/residents within the strong-state tradition of Turkey (Köker, 1995; Keyman and İçduygu, 2003) undermined the respondents' work and rights to represent residents in formal politics. The muhtars limited their representative role to "guide residents within the governmental system". To get involved in that system, only a few (mostly female) muhtars deployed certain daily tactics, some of which were gendered. It was especially important to be included in the (in)formal networks around doing public works that operate along with the maledominated patron-client relationships at multiple scales of the state apparatus. 
Surely such daily tactics positively affect those men's, and especially women's, conditions for political participation. However, these tactics alone cannot improve the uneven conditions for citizen participation. In Turkey, the state historically mediates and even reconstructs the multi-scalar power relations affecting individuals, groups, locales or any public offices. It does so by its agencies and regulations for redistributing wealth and welfare entitlements (Garcia, 2006; Swyngedouw, 2005) and also with its construction of the locales, local offices (Köker, 1995; Arıkboğa, 1999) and the nature of Turkish citizenship as being mostly with the responsibilities (rather than rights) (Keyman and İçduygu, 2003) for empowering the centralist nation-state.

Since the early 2000s, the Turkish state has implemented a variety of local projects to improve citizen participation, some of which are part of the transition process to EU membership. Yet such local projects need to be developed as part of broader legal, administrative or even constitutional changes (Beall, 2005, 2007); for instance, the hierarchical structure between central and local authorities, reformulating the neighbourhood offices as governing or representative units of different citizenship claims and widening citizenship rights to reflect not only religious, sectarian and ethnic identities (i.e. the common subjects of the recent discussions about Turkish citizenship), but also gender differences in political participation. Opening new terrains for citizen participation, such forms of state-driven change might reduce the impact of patriarchal and clientelist networks hindering women's political participation.

\section{Acknowledgements}

I would like to thank the Izmir Institute of Technology for funding this study (project number: 2007IYTE22). I am also grateful to all of the study respondents who generously shared their stories, and for the insightful comments of three anonymous reviewers.

\section{References}

Alkan, A. (2009) Gendered structures of local politics in Turkey, Digest of Middle East Studies, 18(1), pp. 31-56.

Appelbaum, S. H., Audet, L. and Miller, J. C. (2003) Gender and leadership? Leadership and gender?, Leadership and Organization Development Journal, 24(1), pp. 43-51.

Arat, Y. (1989) The Patriarchal Paradox: Women Politicians in Turkey. London: Associated University Presses.

Arıkboğa, E. (1999) Yerel yönetim açısından mahalle muhtarlığına bir bakış, Çă̆ daş Yerel Yönetimler Dergisi, 8(3), pp. 103-125.

Arıkboğa, E., Erkan, N. E. and Güner, A. (2010) The rise of women in local politics in Turkey: whereabouts? Up to where? Paper presented at the 1st International Congress on Urban and Environmental Issues and Policies, Trabzon, Turkey, June.

Beall, J. (2005) Decentralizing government and decentering gender: lessons from local government reform in South Africa, Politics \& Society, 33, pp. 253-276.

Beall, J. (2007) Decentralization, women's rights and development. Institute of Development Studies, London School of Economics.

Certeau, M. de (1984) The Practice of Everyday Life. Berkeley, CA: University of California Press.

Çitci, O. (1989) Yerel Yönetimlerde Temsil: Belediye Örneği. TODAİE Yayınları, Ankara.

Cleaver, F. (2004) The social embeddedness of agency and decision-making, in: S. Hickey and G. Mohan (Eds) Participation: From Tyranny to Transformation?, pp. 271-277. London: Zed Books.

Cornwall, A. (2004) Spaces for transformation?, in: S. Hickey and G. Mohan (Eds) Participation: From Tyranny to Transformation? pp. 75-91. London: Zed Books.

Eagly, A. H. (2007) Female leadership advantage and disadvantage, Psychology of Women Quarterly, 31, pp. 1-12. 
Evertzen, A. (2001) Gender and Local Governance. Netherlands Development Organization, Amsterdam.

Fisher, R. and Kling, J. (Eds) (1993) Mobilizing the Community. Newbury Park, CA: Sage Publications.

Garcia, M. (2006) Citizenship practices and urban governance in European cities, Urban Studies, 43(4), pp. 745-765.

Güneş-Ayata, A. (1991) Women's participation in politics in Turkey, in: S. Tekeli (Ed.) Women in Modern Turkish Society. Istanbul: Iletisim Yayinlari.

Güneş-Ayata, A. (1994) Roots and trends of clientelism in Turkey, in: L. Roniger and A. Güneş-Ayata (Eds) Democracy, Clientelism, and Civil Society, pp. 49-64. Boulder, CO: Lynne Rienner Publishers.

Güneş-Ayata, A. and Tütüncü, F. (2008) Critical acts without a critical mass, Parliamentary Affairs, 61(3), pp. 461-475.

Keyman, E. F. and İçduygu, A. (2003) Globalization, civil society and citizenship in Turkey: actors, boundaries and discourses, Citizenship Studies, 7(2), pp. 219-234.

Köker, L. (1995) Local politics and democracy in Turkey: an appraisal, The Annals of the American Academy of Political and Social Science, 540(July), pp. 51-62.

Lister, R. (1997) Citizenship: Feminist Perspectives. Basingstoke: Macmillan.

Lovenduski, J. (2001) Women and politics, Parliamentary Affairs, 54, pp. 743-758.

Lovenduski, J. (2005) Feminizing Politics. Cambridge: Polity.

Marston, S. A. (2000) The social construction of scale, Progress in Human Geography, 24(2), pp. 219-242.

Ministry of Interior (2011) The Report of 2010. General Directorate of the Local Administration (http://www.migm.gov.tr/Yayinlar. aspx.)

Naples, N. A. (Ed.) (1998) Community Activism and Feminist Politics: Organizing across Race, Class, and Gender. London: Routledge.

Norris, P. and Inglehart, R. (2000) Cultural Barriers to Women's Leadership. Boston, MA: IPSA.

Norris, P. and Lovenduski, J. (1993) Gender and party politics in Britain, in: J. Lovenduski and P. Norris (Eds) Gender and Party Politics, pp. 35-59. London: Sage Publications.
Phillips, A. (1995) The Politics of Presence. New York: Clarendon Press.

Sancar-Üşür, S. (2003) Women in state, politics and civil society, in: Bridging the Gender Gap in Turkey. World Bank Report: Europe and Central Asia Region, pp.167-180.

Schwindt-Bayer, L. A. (2005) The incumbency disadvantage and women's election to legislative office, Electoral Studies, 24, pp. 227-244.

Scott, J. W. (1999) Gender and the Politics of History. New York: Columbia University Press.

Senol, F. (2009) Women running for neighbourhood offices in a Turkish city: motivations and resources for electoral candidacy, Political Geography, 28, pp. 362-372.

Staeheli, L. A. and Clarke, S. E. (1995) Gender, place, and citizenship, in: J. A. Garber and R. S. Turner (Eds) Gender in Urban Research, pp. 3-23. Thousand Oaks, CA: Sage Publications.

Studlar, D. T. and McAllister, I. (1991) Political recruitment to the Australian legislature, Western Political Quarterly, 44(2), pp. 467-485.

Swyngedouw, E. (2005) Governance innovation and the citizen: the Janus face of governancebeyond-the-state, Urban Studies, 42(11), pp. 1991-2006.

Thomas, S. (1994) How Women Legislate. Oxford: Oxford University Press.

TUIK (Türkiye Istatistik Kurumu) (2008) Turkish Statistical Institute website (http://www. turkstat.gov.tr; accessed 14 February 2012).

Turnhout, E., Bommel, S. V. and Aarts, N. (2010) How participation creates citizens: participatory governance as performative practice, Ecology and Society, 15(4), pp. 26-40.

Urbinati, N. and Warren, M. E. (2008) The concept of representation in contemporary democratic theory, Annual Review of Political Science, 11, pp. 387-412.

Verba, S., Schlozman, K. L. and Brady, H. E. (1995) Voice and Equality. Cambridge, MA: Harvard University Press.

Wängnerud, L. (2009) Women in parliaments: descriptive and substantive representation, Annual Review of Political Science, 12, pp. 51-69.

Wedel, H. (2001) Siyaset ve Cinsiyet: Istanbul Gecekondularında Kadınların Siyasal Kat1lımı. İstanbul: Metis Yayınları. 